\title{
ANALISIS SEMIOTIKA COVER MAJALAH TEMPO EDISI 4 - 11 JUNI 2018
}

\section{SEMIOTIC ANALYSIS ON THE COVER OF THE TEMPO MAGAZINE EDITION 4 - 11 JUNE 2018}

\author{
Nugroho Abraham Akbar \\ Mahasiswa Peminatan Public Relations, Stikosa - AWS \\ Email : abrahamakbar2@gmail.com
}

\begin{abstract}
Layout placement magazine is the most attention, because magazines have more space for pictures and photos. So images or photos can represent the contents of news or information delivered. A photo in a magazine must have information to clarify the photo. In addition to content with an attractive layout, something that draws attention to the magazine is the cover. In this study, the authors used a qualitative research method with a semiotic approach method. Semiotics Charles Sanders Pierce, the signs in the picture can be seen from the types of signs that are classified in semiotics. Among them: icons, indexes and symbols. The result is that every element contained in the cover produces meaning that can be understood by anyone who reads it. Because each photo is illustrated with a picture of each character in it. As for the other signs that are in it are also discussed based on the meaning and function of its use.
\end{abstract}

Keywords: magazine cover, semiotics, Charles Sanders Pierce

\begin{abstract}
ABSTRAK
Dalam sebuah majalah, penempatan tata letak menjadi hal yang paling diperhatikan. Karena majalah memiliki ruang yang lebih banyak untuk gambar dan foto. Sehingga gambar atau foto bisa mewakili isi dari berita atau informasi yang disampaikan. Sebuah foto pada majalah haruslah memiliki keterangan untuk memperjelas foto tersebut. Selain isi dengan tata letak yang menarik, sesuatu yang menjadin perhatian pada majalah adalah covernya. Didalam penelitian ini, penulis menggunakan metode penelitian kualitatif dengan metode pendekatan semiotika. Semiotika Charles Sanders Pierce, maka tanda-tanda dalam gambar dapat dilihat dari jenis tanda yang digolongkan dalam semiotik. Diantaranya: ikon, indeks dan simbol. Hasilnya setiap elemen yang terdapat di dalam cover tersebut menghasilkan makna yang dapat dipahami oleh siapa saja yang membacanya. Karena pada setiap foto yang diilustrasikan dengan gambar dari setiap tokoh yang berada di dalamnya. Sedangkan untuk tanda-tanda lainnya yang berada didalamnya juga dibahas berdasarkan pemaknaan dan fungsi dari penggunaannya.
\end{abstract}

Kata kunci : cover , majalah , semiotika, Charles Sanders Pierce

ISSN 2338 - 0861 (cetak); e-ISSN 2621 - 8712 (online)

website : http://spektrum.stikosa-aws.ac.id 


\section{PENDAHULUAN}

Dalam kehidupan sehari-hari kita tak bisa lepas dari yang namanya komunikasi massa. Komunikasi massa menggunakan media untuk menyebarkan informasi kepada khalayak. Karena media massa merupakan alat yang mampu mempengaruhi, membentuk opini publik dan atau bahkan menjadi alat kontrol sosial. Karena media massa memiliki fungsi dasar, yaitu fungsi menyiarkan (to inform), fungsi mendidik (to educate), fungsi menghibur (to entertain), fungsi mempengaruhi (to influence).

Berdasarkan jenisnya, media massa terbagi menjadi dua, yaitu : media massa cetak (Koran, majalah, tabloid, dll) dan media massa elektronik (radio, televisi, dll). Media massa cetak memang sudah jauh lebih dulu hadir dan dikenal masyarakat. Sedangkan media elektronik hadir seiring dengan perkembangan teknologi. informasi juga bisa sangat menarik sesuai dengan pengemasan dari informasi tersebut. Jenis media yang digunakanjuga beragam dan bisa menyesuaikan kebutuhan dari pembancanya. Selain media yang berbentuk visual, audio danjuga penggabungan dari visual dan audio.

Dalam sebuah majalah, penempatan tata letak menjadi hal yang paling diperhatikan. Karena majalah memiliki ruang yang lebih banyak untuk gambar dan foto. Serta warna yang lebih banyak dibandingkan dengan Koran. Sehingga gambar atau foto bisa mewakili isi dari berita atau informasi yang disampaikan. Sebuah foto pada majalah haruslah memiliki keterangan untuk memperjelas foto tersebut. Selain isi dengan tata letak yang menarik, sesuatu yang menjadin perhatian pada majalah adalah covernya.

Karena dari sebuah cover itu dapat mewakili isi majalah tersebut dan kemungkinan dari sebuah cover dapat memiliki makna yang sangat luas yang dapat ditafsirkan pembacanya. Cover majalah akan mengikuti dengan isu yang berkembang serta pembahasan pada majalahnya. Hal utama yang langsung dituju dari pembaca majalah adalah cover, sehingga semakin menarik, maka akan semakin membuat orang penasaran untuk membaca isinya. Apalagi bila yang ditampilkan dalam cover, foto/ ilustrasi yang sedang hangat pada saat ini.

Pada sebuah cover majalah, ilustrasi digunakan sebagai gambaran pesan yang tidak terbaca, namun bisa mewakili cerita dalam bentuk grafis yang menarik. Dengan ilustrasi atau gambar yang berkaitan dengan peristiwa yang sedang terjadi. Maka pesan menjadi lebih berkesan, karcna pcmbaca akan lebih mudah tnengingat gambar dari teks. Dalam sampul pemilihan judul harus singkat, mudah dibaca, mudah dimengerti dan secara langsung dapat meginformasikan isi yang terkandung dalam buku atau majalah.

Pada penelitian ini peneliti memilih Majalah TEMPO Edisi 4-11 juni 2018 sebagai objek yang akan diteliti, karena majalah tersebut merupakan media massa (cetak) yang sering menampilkan beberapa kankaktur atau gambar sebagai sampul yang bersifat kritis dalam memberikan informasi untuk khayalak di segala bidang baik sosial, politik, maupun ekonomi.

Semiotika ialah cabang ilmu dari filsafat yang mempelajari "tanda" dan bisa disebut dilsafat penanda. Tanda adalah segala sesuatu yang dapat mewakili sesuatu atau sesuatu 
yang dapat dimaknai sebagai penggantian untuk sesuatu lainnya. Semiotika adalah teori analisis berbagai tanda dan pemaknaan, secara umum, semiotika didefinisikan sebagai teori filsafat umum yang berkenaan dengan produksi tandatanda dan simbol-simbol sebagai bagian dari sistem kode yang digunakan untuk mengkomunikasikan informasi.

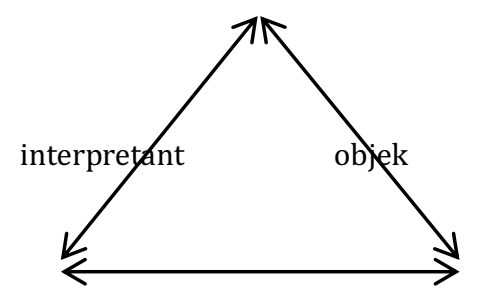

Gambar 1. unsur makna dari Pierce

Semiotika Charles Sanders Pierce, maka tanda-tanda dalam gambar dapat dilihat dari jenis tanda yang digolongkan dalam semiotik. Diantaranya: ikon, indeks dan simbol. Ikon adalah tanda yang mirip dengan obyek yang diwakilinya. Dapat pula dikatakan, tanda yang memiliki ciriciri sama dengan apa yang dimaksudkan.

Semiotika Charles Sanders Pierce, maka tanda-tanda dalam gambar dapat dilihat dari jenis tanda yang digolongkan dalam semiotik. Diantaranya: ikon, indeks dan simbol. Ikon adalah tanda yang mirip dengan obyek yang diwakilinya. Dapat pula dikatakan, tanda yang memiliki ciriciri sama dengan apa yang dimaksudkan.

Indeks merupakan tanda yang memiliki hubungan sebab akibat dengan apa yang diwakilinya. Atau disebut juga tanda sebagai bukti. Simbol merupakan tanda yang dikonvensi, peraturan atau perjanjian yang disepakati bersama Dalam teori segitiga makna terdapat 3 elemen pembentukan tanda yaitu Representamen (Dalam cara tanda menampilkan diri) yang terdiri atas: Qualisign (Tanda yang menunjukan karakter sifatnya), Sinsign (Cara ia menampakan diri disepakati semata), Legisign (Tanda menampakan dirinya sebagai norma). Object yang terdiri atas: Icon (Jika tanda dengan acuan memiliki hubungan kemiripan), Index (Tanda yang dengan acuannya mełniliki hubungan sebab-akibat), Symbol (Tanda dengan acuannya disepakati semata).

Table 1. Pembagian Jenis Tanda

\begin{tabular}{|l|l|l|}
\hline Jenis & $\begin{array}{l}\text { Hubungan } \\
\text { antara tanda } \\
\text { dan sumber } \\
\text { acuannya }\end{array}$ & contoh \\
\hline Ikon & $\begin{array}{l}\text { Tanda } \\
\text { berhubungan } \\
\text { dengan objek } \\
\text { karena adanya } \\
\text { keserupaan }\end{array}$ & $\begin{array}{l}\text { Potret / } \\
\text { Foto }\end{array}$ \\
\hline Indeks & $\begin{array}{l}\text { Adanya } \\
\text { kedekatan } \\
\text { eksistensi antara } \\
\text { tanda dengan } \\
\text { objek atau } \\
\text { adanya } \\
\text { hubungan sebab } \\
\text { akibatnya }\end{array}$ & $\begin{array}{l}\text { Asap } \\
\text { adanya } \\
\text { api }\end{array}$ \\
\hline Symbol & $\begin{array}{l}\text { Hubungan ini } \\
\text { bersifat } \\
\text { konvensional } \\
\text { dalam arti } \\
\text { adanya } \\
\text { persetujuan } \\
\text { tertentu antara } \\
\text { para pemakai } \\
\text { tanda }\end{array}$ & $\begin{array}{l}\text { Simbol } \\
\text { dalam } \\
\text { perjanji } \\
\text { an } \\
\text { masyar } \\
\text { akat }\end{array}$ \\
\hline
\end{tabular}

\section{METODE PENELITIAN}

Penelitian tentang cover dari majalah Tempo ini menggunakan pendekatan metode riset deskriptif kualitatif, yang bertujuan untuk menjelaskan fenomena secara mendalam melalui penggumpulan data sedalam-dalamnya. Metode yang dipakai dalam penelitian ini adalah 
analisis semiotika Charles Sanders Pierce.

\section{HASIL DAN PEMBAHASAN}

Analisis semiotika Charles Sanders Pierce dengan teori segitiga makna yang dikembangkannya. Pierce melihat tanda (representament) sebagai bagian yang tidak terpisahkan dari objek referensinya serta pemahaman subjek atas tanda (interpretant).

Model triadik Peirce (representamen + objek + interpretan $=$ tanda) memperlihatkan peran besar subjek dalam proses tranformasi bahasa. Dalam penulisan makalah ini memakai objek kajian berupa iklan gambar tentang cover majalah tempo seperti gambar dibawah ini:

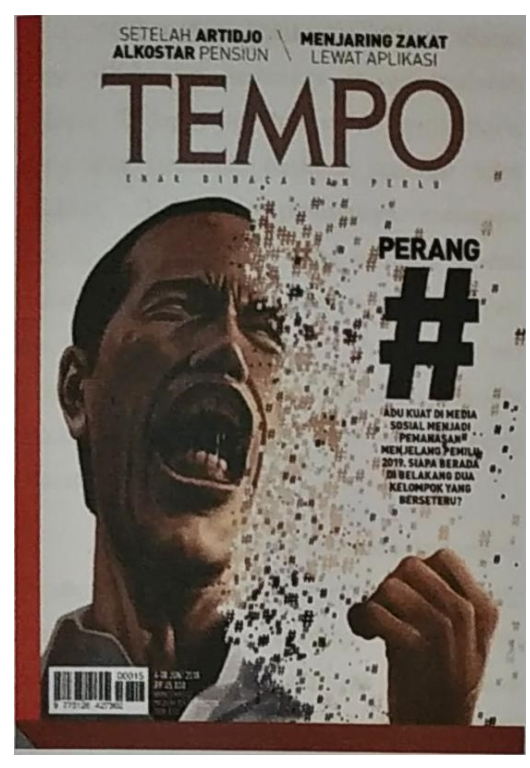

Gambar 2. Cover Majalah Tempo

Bedasarkan identifikasi tanda dalam cover majalah Tempo yang dilakukan dengan mengadaptasi jenijenis tanda yang dikemukakan oleh Pierce. Maka tanda-tanda berupa ikon, indeks dan simbol.
Table 2. Interpretasi Makna Bedasarkan Identifikasi Tanda Ikon

\begin{tabular}{|c|c|c|}
\hline $\begin{array}{l}\text { Jenis } \\
\text { Data }\end{array}$ & Penjelasan & Unit Analisis \\
\hline Ikon & $\begin{array}{l}\text { Tanda } \\
\text { berhubunga } \\
\mathrm{n} \text { dengan } \\
\text { objek karena } \\
\text { adanya } \\
\text { keserupaan }\end{array}$ & $\begin{array}{l}\text { - Gambar } \\
\text { JokoWidodo } \\
\text { - Gambar wajah } \\
\text { yang hilang } \\
\text { berbentuk }\end{array}$ \\
\hline Indeks & $\begin{array}{l}\text { Adanya } \\
\text { kedekatan } \\
\text { eksistensi } \\
\text { antara tanda } \\
\text { dengan } \\
\text { objek atau } \\
\text { adanya } \\
\text { hubungan } \\
\text { sebab } \\
\text { akibatnya }\end{array}$ & $\begin{array}{l}\text { - Pakaian laki- } \\
\text { laki dan } \\
\text { warnanya }\end{array}$ \\
\hline Symbol & $\begin{array}{l}\text { Hubungan } \\
\text { ini bersifat } \\
\text { konvensiona } \\
\text { l dalam arti } \\
\text { adanya } \\
\text { persetujuan } \\
\text { tertentu } \\
\text { antara para } \\
\text { pemakai } \\
\text { tanda }\end{array}$ & Teks Headline \\
\hline
\end{tabular}

Bedasarkan hasil identifikasi diatas yang dilakukan terhadap cover majalah Tempo. Didapatkan dua tanda jenis ikon. Pada ikon pertama, terdapat gambar Joko Widodo. Disini interpretantnya mengacu kepada sosok Jokowi yang terlihat seperti sedang berteriak sambil mengepalkan tangan kearah depan. Dari raut wajah keseluruhan terlihat jokowi seperti menahan sesuatu sambil berteriak dengan raut wajah yang seperti orang marah.

Sebagai seorang Presiden Indonesia dikenal yang selalu berpenampilan yang biasa saja dengan balutan baju warna putihnya. Gaya berpakaiannya menunjukan ia adalah seorang yang sederhana. Sosok Jokowi yang sederhana ini dan menggunakan pakaian khasnya yaitu 
baju kotak-kotak serja kemeja putih, ini merepresentasikan makna ia adalah seorang Presiden dengan kesehariannya yang sederhana.

Pada ikon kedua terdapat gambar serpihan wajah yang hilang berbentuk seperti \#. Interpretantnya mengacu kepada serpihan wajah Joko Widodo yang berbentuk seperti \#. Kita ketahui bahwa saat ini menjelang pemilihan umum, urusan tanda pagar telah menjadi ramai di media sosial. Para masyarakat yang kontra dengan Presiden Joko Widodo menyebarkan \#2019GantiPresiden itu adalah bentuk kampanye untuk mencegah Jokowi terpilih lagi pada pemilu tahun depan.

Jika ikon pertama dan kedua dihubungkan maka interpretasi yang terbentuk ialah majalah Tempo sedang berupaya menyampaikan makna dari perang hastag yang terjadi saat ini membuat Jokowi kehilangan beberapa persen dari dukungan masyarakat Indonesia dalam pemilu 2019 tahun depan.

\section{Interpretasi Makna Bedasarkan Identifikasi Tanda indeks}

Untuk indeks yang pertama ialah baju yang dikenakan oleh Joko Widodo, hubungan tanda dengan objek menuju pada gaya pakaian yang khas dari Joko Widodo yang selalu terlihat sederhana tapi berkelas. Di dalam cover Joko Widodo digambarkan secara visual dengan menggunakan sebuah kemeja wama putih yang selalu ia gunakan.

Dalam cover tersebut pakaian Joko Widodo menampilkan kesan formal tapi sederhana dengan balutan kemeja berwarna putih. Warna putih mengambarkan disiplin, bersih, suci kebaikan, kemurnian, kesederhanaan, kerendahan hati. Hubungan interpretasi antara cover Tempo dengan pakaian Jokowi, Seperti halnya Jokowi yang merupakan Presiden dengan citra kesederhanaanya. Hal ini diciptakan untuk membuat masyarakat percaya dan juga membangun citra positif dari kesederhaan tadi.

\section{Interpretasi Makna Bedasarkan Identifikasi Tanda Simbol}

Terdapat satu simbol dalam cover majalah Tempo, pada tipe simbol yang pertama adalah Headline dari cover itu sendiri, yaitu teks " Perang \# Adu kuat di media sosial menjadi pemanasan menjelang pemilu 2019. Siapa berada di belakang dua kelompok yang berseteru?".

Makna dari headline tersebut mengacu padaperagn hastag yang akhir-akhir ini sering terjadi di media sosial karena menjelang pemilu 2019. Dari situ juga kita ketahui dari perang tersebut pasti ada dalang yang terlibat dibclakang kelompok yang berseteru tersebut, karena tidak mungkin kalau ada asap tidak ada api. Kalimat ini mencoba memancing rasa ingin tahu pembaca terhadap perang \# yang sedang terjadi dan juga agar mau mengikuti berita dari majalah Tempo.

Dalam pembahasan ini akan ulas tentang cover majalan Tempo edisi 4-11 juni 2018 yang menjadi bahan analisa dari penulis. Penggunaan tanda tagar (\#) bukan tanpa alasan, pada tanda \# digunakan sebagai penanda tanda kunci atau topik dalam sebuah postingan di media sosial.

Pada akhir-akhir ini media sosial ramai dengan sebuah hastag \#2019gantipresiden. Akhir-akhir ini terdapat perang hastag di media sosial antara kelompok yang pro dan kontra dengan kepemimpinan Jokowi saat ini. Kemudian munculnya hastag 
\#2019tetappresiden untuk melawan hastag sebelumnya.

Jokowi sendiri nampaknya melihat hastag yang lagi viral tersebut dengan menganggap tagar dengan dan langsung ditanggapi nya dengan santai. Di Bogor, Jawa Barat, ia menyebutkan hanya bisa diganti oleh rakyat, bukan oleh kaus bertuliskan \#2019GantiPresiden. (dikutip dari Tribunnews.com).

\section{KESIMPULAN}

Dari pembahasan tentang analisa semiotika pada foto cover majalah Tempo edisi 4-11 Juni 2018, dapat disimpulkan bahwa setiap elemen yang terdapat di dalam cover tersebut dapat dikaji dan menghasilkan makna yang dapat dipahami oleh siapa saja yang membacanya, Karena pada setiap foto yg diilustrasikan dengan gambar dari setiap tokoh yang berada di dalamnya.

Sedangkan untuk tanda-tanda lainnya yang berada didalmnya juga dibahas berdasarkan pemaknaan dan fungsi dari penggunaannya. Sehingga cover yang awalnya hanya orangorang tertentu saja yang memahami, setelah penulis membahas dengan menggunakan analisa semiotika dari Pierce. Makna yang awalnya hanya sulit dipahami kini bisa lebih mudah dipahami. Sehingga siapa saja yang melihat cover sudah bisa memahami pemberitaan apa yang ada didalam majalah tersebut. Apalagi penggunaan ilustrasi yang menarik, edukatif, menghibur serta segar untuk dikaji.

Dalam pembahasan di atas juga terangkan bahwa makna yang terkandung didalamnya adalah mewakili dari fenomena hastag yang ada di media sosial saat ini dan ramai diperbincangkan oleh banyak orang. Yang mana dalam suasana menunggu pemilu 2019 nanti, namun sudah banyak masyarakat yang pro dan kontra dengan Jokowi menjadi Presiden lagi di tahun 2019.

\section{DAFTAR PUSTAKA}

Buku

Effendy, Onong Uchana, 2011, 11mu Komunikasi : Teori dan Prakteknya. Bandung: Remaja Rosdakarya.

Mulyana, Dedy, 1999, Metode Penelitian Kualitatif. Bandung: Remaja Rosdakarya.

Sobur, Alex, 2009, Semiotika Komunikasi. Bandung: Remaja Rosdakarya.

Sobur, Alex, 2012, Analisis Teks Media.2012. Bandung : Remaja Rosdakarya.

Tinarbuko, Sumbo, 2008, Semiotika Komunikasi Visual. Yogyakarta: Jalasutra.

Rakhmat, Jalaludin, 2008, Psikologi Komunikasi. Bandung: Remaja Rosdakarya.

\section{Jurnal online}

Patriansyah Mukhsin, 2014, Analisis Semiotika Charles Sanders Peirce Karya Patung Rajudin Berjudul Manyeso Diri. Jurnal Ekspresi Seni, https://journal.uny.ac.id/index.p $\mathrm{hp} /$ informasi/article/viewFile/1 3606/pdf. 